\title{
報告
}

\section{パネルディスカッション「図書館における円滑な資料提供の ために」：分担収集・分担保存を中心に}

山崎 美智子*

北里大学医学図書館

関東地区医学図書館協議会では，地区会の事業 の一環として, 研修会を開催している。平成 9 年 度の研修会は, 分担収集と分担保存についての, パネルディスカッションを計画し実行した。

パネルディスカッション

日 時: 平成 10 年 1 月 30 日（金）

午後 1 時 $~ 4$ 時 30 分

場 所: 国立公衆衛生院講堂

テーマ:図書館における円滑な資料提供のために 一分担収集・分担保存を中心に一

パネリスト：

1.「関東地区医学図書館協議会逐次刊行物分担 収集・保存委員会」の活動について

宇野彰男（関東地区医学図書館協議会逐次刊行物 分担収集・保存委員会委員長)

2. 共同書庫センター（仮称）検討会の活動につ いて

下村政光（共同書庫センター（仮称）検討会世話 人)

3. 医学資料保存システム構築に向けて

上田照賀（日本医学図書館協会資料保存委員会委 員長)

\footnotetext{
*Michiko YAMAZAKI : ₹228-8555 相模原市北里 1-15-1. yamazaki@mlib.kitasato-u.ac.jp
}

（1998年 4 月 17 日 受理）
4. 国立国会図書館における今後の科学技術情報 提供のあり方之関西館

福田 理（国立国会図書館科学技術資料課課長補 佐)

5。円滑な資料提供のために一浦安市立図書館の 事例 -

常世田 良（浦安市立図書館長）

6。学術雑誌の流通動向およびオンラインジャー ナルの可能性

深田良治（エルゼビアサイエンスジャパン日本支 社長）

はじめに，司会者からパネリストの紹介と，こ のパネルディスカッションの計画の意図等につい て報告した。

関東地区では，昭和 57(1982)年に地区の事業 として「マイナー逐次刊行物分担保存」の事業を 開始した（医学図書館 1982;29(4):433-5 参照)。 平成 8 (1996)年の見直しの時期にあたって，「関 東地区マイナー逐次刊行物」の現状調査をするた めアンケート調査を行った。その結果である「マ イナー逐次刊行物分担保存訫実状調查」のま之め や，ここ数年来の外国雑誌の高騰とそれに追い打 ちを掛けるような円安による各図書館の予算の逼 迫，その他多くの要因から分担保存のみではなく， 分担収集についても検討すべきとの考えに至った。 地区会の「マイナー逐次刊行物分担保存」事業は, 
平成 9 年 7 月に発展的解消をし，「逐次刊行物分 担収集・保存委員会」が新たに組織された。関東 地区のこの事業をより有効に発展させるきっかけ にしたいとの考えから, 広く医学図書館以外から あパネリストとしてご協力いただいた。

以下に発表内容の要約を記す。

\section{1.「関東地区医学図書館協議会逐次刊行物分担 収集・保存委員会」の活動について}

関東地区医学図書館協議会で実施してきた「マ イナー逐次刊行物分担保存」事業については, 昭 和 57 年にマイナー逐次刊行物の分担保存を実施 して 16 年が経過した。当初 3 年ごとの見直しを 行うことになっていたが，この間実際には 2 回の 見直しが行われ, 現在 89 タイトルを 39 館が分担 保存している。第 3 回目の見直しに向けて平成 8 年実状調査を実施した。この結果を踏まえ, マイ ナー逐次刊行物に限定されていた分担保存対象を 拡充し，分担収集および分担保存を常設的に検討 するための委員会の設置が, 平成 9 年 5 月の地区 会において決定された。

委員会では, これまでのマイナ一逐次刊行物の 分担保存の見直しに加え，より幅広い見地で分担 収集・分担保存を検討することとした。ただし図 書については対象とせず，委員会の名称を「逐次 刊行物分担収集・保存委員会」とした。平成 9 年 7 月に第 1 回を開催し, 現在 4 回委員会を開催し て検討を行っている。

委員会では $3 つ の$ 柱で検討を進めることとした。

\section{1) マイナー雑誌の見直し}

平成 8 年度に実施した，アンケートの結果で出 た問題点を踏まえて，再度アンケート調査を実施 する。

\section{2 ) 分担収集}

医学関係学術雑誌の創刊誌を, 関東地区各館で 分担して収集することができるか，実現の可能性 について検討する。

\section{3）分担保存}

マイナー逐次刊行物以外の雑誌についても, 分 担保存の対象誌として検討の幅を広げる。対象誌 を決めるための前作業を実施する。

この 3 項目についてアンケート調査を近々に実 施することで準備を進めている。

\section{2. 共同書庫センター（仮称）検討会の活動につ いて}

平成 6 (1994)年 10 月に図書資料収納スペース の逼迫した関東地区の医学図書館有志 6 館が集ま り，共同保管（保存）の可能性について検討を始 めた。一時中断したが平成 8 (1996) 年 12 月に共 同書庫センター（仮称）検討会として再発足した。 その後一定の方向性がまとまり, 平成 9 年 6 月に 関東地区医学図書館協議会のメンバー館にアンケー 卜調査を行った。その結果の分析を通して，今後 の対応について検討している。共同書庫センター の考え方の背景について話す前に，まず分担保存 之共同保存の使い分けを次のように意味づける。 分担保存は各図書館の書庫スペースを使って分担 保存をする。共同保存は，第 3 の別の場所を確保 して共同保存をする。これには費用がかかる。し かし各図書館が新しい図書館を建築する費用や， 貸倉庫にかかる経費を考えたとき，可能性が考え られるのではないか。

アンケート調査の回収率は $75.6 \%$ でった。 調查結果から多くの問題点が明確になった。

分担保存の動きは，かなり以前からあったが実 現には至らなかった。実現しなかった要因を分析 しなくてはならないが, 大学図書館研究の掲載論 文の中で，6つの点を指摘している。

（1）必要な資料は全て自館で揃えるべきだと考 えている図書館が多い。そのため共同で蔵書構築 を行うとの理念がそしい。

（2）蔵書構成を行うにあたって, 学外のニーズ が要素とはなりにくい。 
（3）収集，保存および廃棄について，自館のフ リーハンドを確保したい図書館が多い。

（4）同様な専門分野の大学図書館間では，蔵書 内容が類似する傾向がある。そのため，ユニーク な資料は，大規模な図書館に集中しており，分担 格差が生じ易い。

（5）収集基準が明確でないか，始終変わるため 長期的な収集保存方針が確立できない図書館があ る。

（6）他館の資料所蔵情報へのアクセスが容易で ない。

しかしながら，共同書庫センターのようなあの ができれば，解決する問題は多くある。共同書庫 保存センターを実現するためには，事業の推進委 員会を組織し助成金を貪う。財団法人組織として 機能させ，運営できるよう企画推進する人材を雇 用する等いろいろ考えられるが，努力することに より，実現は決して夢物語ではないと考える。

\section{3. 医学資料保存システム構築に向けて}

\section{1）資料保存委員会について}

この委員会は, 平成 8 年度に日本医学図書館協 会の理事会で承認され, 平成 9 年 1 月に活動を開 始し, 現在まで 4 回の委員会を開催した。

\section{2) 医学図書館の資料保存の現状について}

この委員会では八ード面の収納のスペースの問 題, ソフト面から保存のシステムについてという 2 項について検討することにした。

国立大学図書館協議会保存図書館に関する調査 研究班の「保存図書館に関する調查研究」を参考 に検討を進めてきた。委員会での検討事項の中で, 現状把握のため加盟館へアンケートを実施するこ ととし, 平成 9 年 7 月に「資料保存の現状に関す るアンケート」調査を行い, 11 月に集計結果の 報告書を出した。

\section{3) 医学図書館を取り巻く環境 : 主として 学術情報システムを中心に}

昭和 61 年に学術情報センターが設置され，そ れに伴い全国の大学図書館の学術情報を有効利用 することが進められた。国立国会図書館との連携, また国立大学の外国雑誌センター館の活動によっ て, 医学図書館を取り巻く環境は大きく変化して きている。

\section{4 ) 保存スペースの問題について}

主としてハード面の対応であるが，多くの問題 を抱えている。それぞれいろいろな所で検討して いるようであるが, 直接的な問題解決には結びつ いていない。本委員会としても協会が全加盟館の 資料を包括して，共同保存していくことは不可能 であると考えている。全国的規模で共同保存図書 館の設立が望まれる。

\section{5）医学資料保存システム機構の方策について}

医学図書館を取り巻く環境で述べた国立大学外 国雑誌センター館, NACSIS, 国立国会図書館, の3つがキーワードと考える。

（1）国立国会図書館との連携について，具体的 方策は今後の検討課題である。

（2）資料の廃棄を前提とした共同保存システム を構築する。これには, 外国雑誌センター館の動 きが重要である。

\section{6 ）他機関，他組織との連携について}

国立大学図書館協議会, 国立国会図書館, 私立 大学図書館協議会等と連携する。さらにはグロー バルな視点から，情報の電子化の可能性に李目を 向けていかねばならない。そして，最終的には国 と国との連携を視野に置き，国家的レベルで刘応 し解決していくことが必要ではないかと考える。

\section{4. 国立国会図書館における今後の科学技術情報 提供のあり方と関西館 \\ 外国雑誌の高騰や資料費の削減，その他電子化 ネットワーク等, 新しい科学技術情報を巡る環境}


の激变の中で, 国立国会図書館は, 科学技術情報 の収集・提供・保存について, 新たな枠組み作り の検討を進めている。

この変革の時代に, 国立国会図書館がどう対応 すべきか，新しい枠組みをどう作るべきかを，平 成 9 年「科学技術関係資料整備審議会」に諮問し, 平成 10 年 2 月に答申されることになっている。 そこでの大きな柱は,

（1）立法補佐機能の強化

（2）利用者のニーズを明確化し，他機関との協 力に基づく資料提供をする

（3）ドキュメント・サプライ・サービスと電子 図書館の実現によるリモート・アクセス・サービ スを図る

（4）高度なレファレンス・サービスと科学技術 情報専門家を育成する

（5）科学技術情報の充実に向けた協力関係の確 立

特に他機関との協力無くしてはサービスはでき ないとの認識であり，目標となっている。当面の 課題はNACSIS や JST との協力関系を結ぶこと が重要と考えている。具体的なことは今後検討し て推進していく。

さらに，2002 年開館予定の関西館の基本機能 は，ドキュメント・デリバリーと迅速性が目標と 考えている。しかしながら近年の社会状況の変化 から電子化ネットワークにも視点を置きサービス をしていく。

関西館の目的は単にドキュメント・サプライ・ デリバリーのみではなく, 図書館本来の業務とし てレファレンスにも力を入れ，電子図書館機能を 果たせるような位置づけで考えている。国内の大 学や, 研究施設と連携し, 図書館利用者の二ーズ を把握し，ドキュメント・サプライに対応する機 関として機能していくことが目標である。

\section{5. 円滑な資料提供のために一浦安市立図書館の 事例}

公共図書館の機能として, 保存についてはほと んよ゙考えられていない。全国的に見ても公共図書 館の 70〜80\%は保存機能を持っていない。しか し10 年くらい前から保存についても考えられる ようになってはきている。公共図書館のタイプと して,

（1）全く保存については考えていない

（2）自館では廃棄して，保存は他館に依存する

（3）自前でも保存機能を持つ

のレベルがある。浦安市立図書館は 3 つめのタイ プである。

利用者のニーズをカバーしようとすれば, 網羅 的に収書しなければならない。市立図書館では， 自館に所蔵していなければ市内の他の図書館，さ らに県立図書館また他県の県立図書館との相互協 力で調達している。これは意識的計画的ではない が分担収集している訳である。しかしアメリカ等 に比べ日本の場合は，図書館間のデリバリー機能 が弱い。また特に公共図書館では所蔵目録が整備 されていないので情報へのアクセスができにくい。 千葉県では保存図書館機能を果たす, 新しい図書 館の設立が計画されている。

公共図書館の利用者は, 児童と主婦とのイメー ジが強いが浦安市の図書館は，児童と一般の利用 者の貸出比は $1 ： 4$ である。幅広い利用者の二ー ズに応えるためには今までは資料の共有化につい て論議していたが, これからは保存機能を共有化 して，館種を越えた連携をして，サービスを展開 していくことが必要になってくる。

アメリカではコンソーシアムという形でいろい ろな図書館が館種を越えて, サービスや保存に連 携している。

(この後, 障害者サービスの一つである「病院 に対するサービス」のビデオを上映した。） 
山崎 パネルディスカッション「図書館における円滑な資料提供のために」

6. 学術雑誌の流通動向およびオンラインジャー ナルの可能性

\section{1）情報の需要と供給}

情報のアンバランス, すなわち供給と需要のバ ランスが崩れてきたことが，深刻な問題になって きている。

2) 学術雑誌の宿命, 良い雑誌ほど大きくなる 内容が良くなると論文が多くなり，ボリューム が増加している。

\section{3）学術雑誌の情報伝達, 紙から電子へと移り} つつある

科学技術関連の雑誌は，特にデジタル化されど んどん増加している。現在は，紙の上にある情報 と全く同じものを電子媒体で作成しているが，こ れからは紙と電子媒体は別のあのとして出るので はないか。速報的情報は電子ジャーナルとして世 界中に広がる。アーカイバルなもの，定着した情 報, 保存する資料は, 紙として出版されると考え る。その先は何年先になるかわからないが，アー カイバルなものも，電子化されることになってい くであろう。

4）情報伝達の方法と利用の形態にも変化が見 られる

紙の出版物は，Natureや Science を見ても， 150 年から 200 年の歴史を持っている。電子出版 はせいぜい 5 年の歴史しかないので，単純に比較 はできない。利用の方法が変化している。従来は 利用者が図書館に来て資料を利用していたが，今 の研究者は，オンラインなどで検索し本当に必要 な資料だけを得ている。

\section{5）情報制作の費用，伝達の費用}

出版社が情報を収集することに費用がかかる。 また提供する情報が電子化し，インターネット等 によって収集するとしても，同じょうに費用はか
かる。

6 ）コンソーシアムの可能性

コンソーシアム＝共同利用機構については, 現 在アメリカで「オ八イオリンク」のコンソーシア ムの実現がかなり具体化している。

コンソーシアムとは，どのようなものであるべ きかを考える之，地域別のコンソーシアム，地域 を越えた各専門分野別のコンソーシアム, 研究の 特性に基づいた私立の大学等に集まったコンソー シアムの 3 つらいが考えられる。

\section{7 ）新しい利用形態と価格体制への模索}

価格の付け方に問題が出てくる。将来的に出て くるであろう問題は，固定料金にするとか，1回 毎の利用料金を支払うなど料金体系を模索してい る。問題は，無形のものに対する予算上・事務上・ 会計上の処理であろう。

6 名の発表が終了し, 休咊した後質疑応答を行っ た。

本パネルディスカッションでは，館種を越えた パネリストの方々のご協力により，内容も評議員 館の意図が十分伝わり，有意義な研修会ができた と喜んでいる。

報告を出すにあたり，快くお引き受け下さり， 多くの有効な意見とご示唆を下さったパネリスト の方々に心から感謝申し上げます。

最後に，参考資料として以下の 2 点をあげてお きますので，ご参照下さい。

「科学技術関係資料整備審議会答申」平成 10 年 2 月 国立国会図書館.

「保存図書館に関する調查研究報告書」平成 6 年 3 月 国立大学図書館協議会 保存図書館に関する調查研究 班。 